\title{
A Review on Information Technologies Used in Teaching Turkish as a Foreign Language*
}

\author{
Fatma Gülengül BíRíNCi ${ }^{* *}$
}

\begin{abstract}
In today's globalizing world, information technologies are used in every field of life, and using these technologies in foreign language teaching has become a necessity rather than an option. Enabling learners who frequently use information technology tools in their daily lives to benefit from these technologies while learning a foreign language will have positive effects on their learning and motivation to learn. Information technologies are also used in the field of teaching Turkish as a foreign language, which has gained importance day by day. However, although endless opportunities are provided to the instructors by information technologies, it is seen that these technologies are not utilized sufficiently. In this study, in which qualitative research approach was adopted, information technologies used in foreign language teaching were examined through literature review and technology tools used in teaching Turkish as a foreign language were brought together. In this context, the aim of this study is to provide the instructors with detailed information about the information technology tools used in this field, to increase their awareness about these tools, and thus to contribute to technology enriched teaching of Turkish as a foreign language.
\end{abstract}

Keywords: Teaching Turkish as a foreign language, information technologies, using technology in language teaching, Web 2.0 tools

\footnotetext{
* This study is part of the author's doctoral dissertation entitled "The relationship between information technology self efficacy beliefs of instructors of Turkish as a foreign language" completed with the supervision of Prof. Dr. Mustafa Durmuş at Hacettepe University.

${ }^{* *}$ Orcid ID: https://orcid.org/0000-0002-8045-412X, Assist. Prof. Dr., Hacettepe University, School of Foreign Languages, Turkey, gulenhepgul@gmail.com
} 


\section{INTRODUCTION}

Using information technologies in foreign language teaching, in which using various materials is required, is now a necessity rather than an option. As Durmuş (2019) clarifies, "The place and functions of technological tools in human life have increased so rapidly, so it is not possible to organize language teaching activities effectively without these tools" (p. 101). Enabling learners who frequently use information technology tools in their daily lives to benefit from these technologies while learning a foreign language will have positive effects on their learning and motivation to learn. In addition, using these technologies in foreign language teaching has many benefits not only for learners but also for teachers. The teaching environment becomes more effective thanks to these technologies.

The use of information technologies in foreign language teaching was first started in teaching English as a foreign language in the 1950s and 1960s. A lot of research has been done on using these technologies since then and it has been concluded that information technologies have significant effects on learning (Chen, Belkada \& Okamoto, 2004; Ünsal, 2012; Wang \& Vasquez, 2012). It is also clear that if these technologies are used in teaching Turkish, a more effective teaching process may be obtained. Since teaching Turkish was mostly seen as teaching of a mother tongue in the past, there is not much study on using information technologies in this field. However, recent studies on teaching Turkish as a foreign language have brought new dimensions to teaching Turkish. With the awareness that language teaching is not merely teaching grammar and that different language skills should be taught as well, the number of the studies on using information technologies in teaching Turkish have increased considerably compared to the past. Nevertheless, the desired level has not been reached in this field yet. As Büyükaslan (2007) explains, "When we look at the point reached today in foreign language teaching, we cannot ignore the contribution of information technologies to this field. It is certain that educators who can benefit from information technologies are required so as to use this contribution, to present it as a discipline to teaching Turkish as a foreign language, and to achieve efficiency in this field" (p. 4).

The quality of the teaching environment in foreign language teaching has a pretty big impact on the effectiveness of teaching. The mother tongue of the region where the teaching process is carried out is very effective in the learning process. Thus, teaching Turkish as a foreign language abroad and teaching it in Turkey are considerabley different from each other. The needs of learners who learn Turkish abroad are quite different from those learning in Turkey. These learners are exposed to Turkish only in teaching environment. In addition, language classes abroad in which Turkish is taught as a foreign language are not as homogeneous as in Turkey; the time that learners devote to learning a language and their motivation to learn the target language are also quite different. For this reason, these learners need more information technology tools and these technologies create more differences on their learning than those learners in Turkey (Durmuş, 2019). When considered from the perspective of instructors, the instructors 
who teach Turkish as a foreign language abroad need to use information technologies more and therefore, they should be more active in this field. Being aware of this, studies should be increased and instructors should be supported. In order to reach the desired level in this field, instructors who are qualified, technology literate and know how to integrate technologies with the teaching processes are needed.

The aim of this study is to examine the information technlogies which are currently used or which are appropriate to use in teaching Turkish as a foreign language. Thus, the awareness of the instructors working in this field regarding information technologies will be expanded, they will be informed about these technologies, and so it will contribute to technology enriched teaching.

\section{METHOD}

Qualitative research approach was adopted in this study. The research was conducted in accordance with the survey model since the existing situation is tried to be described as it is. The data of the study were examined within the scope of general survey model, which is one of the documentary survel models. General survey model is known as "literature" or "literature review" in many studies (Karasar, 2016, p. 231). In the literature review conducted in this study, information technologies used in foreign language teaching were examined in detail. Then, information technologies used in teaching Turkish as a foreign language were brought together by reviewing printed and digital documents and scientific studies. As the complete list formed by literature review positively affects the success of the study (Karasar, 2016), special attention was paid to keep the study up-todate.

\section{COMPUTER APPLICATIONS USED IN TEACHING TURKISH AS A FOREIGN LANGUAGE}

Computer programs and applications prepared in the field of teaching Turkish as a foreign language have been gradually increased. The prominent applications and programs which are prepared or can be used in this field are listed as follows:

1. Winmekmak: This program has been designed to explain the mathematical features of Turkish. In this program, the computer can conjugate all the verbs by giving a few rules about vocal harmony. Learners can create sentences by conjugating the words they see in the dictionary.

2. The Turkish Suffix Dictionary: This program is a dictionary prepared by Eva a Csato and David Nathan in 2003, which is used via the Internet and enriched with detailed information about all the supplements of Turkish with explanations in English. 
3. Verbix Verb Conjugator: Verbs of many languages in the world can be conjugated with the help of this program. The verb written in the program appears on the screen in a few seconds with all the details and uses in the selected language (Duru, 2013).

Apart from the above applications, there are many supplementary documents and books prepared for teaching Turkish as a foreign language. Interactive CDs are often included in the content of these books. Moreover, there are many interactive CDs prepared by different organizations independently from these books. The most commonly used interactive CDs in this field are as follows:

1. Euro Talk: These CDs, which try to make learning fun with games, have products in many fields such as business Turkish, tourism Turkish, school Turkish and daily Turkish (Duru, 2013). This program, which was developed by British entrepreneurs, offers products with more than sixty topics in over thirty languages including Turkish. It is very convenient for users because they can download and use it on mobile phones and tablets, and it is used by a large audience worldwide.

2. Rosetta Stone: It is a comprehensive foreign language teaching set prepared to teach thirty languages including Turkish. It is very beneficial for users because of being able to downloaded to mobile phones and tablets and teaching more daily language with pictures, sounds and videos.

Besides these, there are also interactive CDs in the teaching sets of many publishers, and new materials and updates are being prepared in the light of the developing technologies.

\section{WEBSITES DESIGNED FOR TURKISH AS A FOREIGN LANGUAGE}

Websites designed to support the learning and teaching process provide learners with opportunities of summarized topics, educational games, exercises, bulletin boards, homework research and presentations. Designing their own websites and moving them to learning environments also allow students to engage in activities such as general repetititon, problem solving and exercises (Driscoll, 1998). In other words, using websites in learning and teaching environments brings new approaches to the educational processes and enables the development of educational settings. In addition, the most significant opportunity that websites bring to the education process is communication. The interactive learning environment, which is a result of the communication provided by the Internet and computers, enables the learners to communicate with each other, their teachers and learners and teachers from other countries (Uzunboylu, 2005) and even this may be regarded as adequate to include websites and the Internet in foreign language teaching process.

There are lots of websites which can be used in the field of teaching Turkish as a foreign language. Some of these websites are not free, while others are free and prepared for the purpose of sharing the course materials with the collegues. There are also websites which 
offer different types of content such as lectures, material resources, exercises for learners who learn Turkish. Some of these websites are as follows:

1. www.dilbilimi.net : This website has a project part titled "Adım Adım Türkçe Öğreniyorum", which was prepared by Mustafa Altun and this part consists of 6 units and sections within the units. Almost all units have listening and reading texts, grammar explanations and vocabulary exercises. Additionally, sections such as linguistics topics, articles, theses, computer software, educational videos on the website make this site especially important for academic studies (Duru, 2013).

2. www.turkcede.org website is mostly used as a forum. However, the sections of discussions, articles, exemplary lectures, and in-class activities are very useful for lecturers teaching Turkish as a foreign language (Duru, 2013). Moreover, in the "Learning Turkish" section, there is a part consisting of 12 units, which can also be used by learners who want to learn Turkish as a foreign language, with listening and reading texts and exercises.

3. www.turkofoni.org website, which was prepared by Mustafa Çetin, is for learners of Turkish as a foreign language and it contains many e-books, grammar explanations and exercises.

4. http://www.turkishlanguage.co.uk website deals with many aspects of Turkish and it contributes to the teaching of Turkish as a foreign language with explanations in English unter titles such as detailed grammar explanations, exercises, street language and signs.

5. http://learnturkish.pgeorgalas.gr/Default.asp website was prepared by Panagiotis, a teacher in Greece. This completely free website contains many types of content such as videos, exercises, vocabulary activities, TV and radio links, grammar rules and puzzles all of which can be used to learn Turkish as a foreign language.

6. https://www.memrise.com/home/ website has contributed to the teaching of many languages since 2010. This website, which especially emphasizes the expressions used in daily speech, also allows foreigners to learn Turkish.

7. https://yabancilaraturkceogretimi.com/ website, which was prepared by Turkish teachers, shares various original materials, and presents activities designed by different organizations to teachers and learners. There are many types of content on this website such as annual plan samples, proficiency exams, games and activities that can be used in the field of teaching Turkish as a foreign language.

In addition to the websites mentioned above, in a study of Şengül (2012, p. 184-185), the websites listed below are also included in this field. However, most of these websites have limited use such as referrals to other websites, general information, articles, dictionaries, forums and exercises:

- $\quad$ http://onlineturkish.com 
- http://www.turkceogretimi.com/

- http://www.ingilizceturkce.gen.tr/

- http://www.docnmail.com/learnmore/language/turkish.htm

- http://www.turkceciler.com/

- http://users.telenet.be/orientaal/links.html

- http://www.turkishclass.com/turkish learning group 3

\section{WEB 2.0 TOOLS USED IN TEACHING TURKISH AS A FOREIGN LANGUAGE}

Various web applications are used both in daily life and educational processes thanks to the rapidly developing technologies. Different technological terms emerge every day and different web applications are being used. Today, web applications are examined in six different categories. Of these six categories, Web 0.0 represents the developing Internet, Web 1.0 represents the fixed web, Web 2.0 represents the interactive web, Web 3.0. represents the semantic web, Web 4.0 represents the portable / mobile web, and Web 5.0 represents the open, connected and smart web-emotional web (Gün, 2015). However, today, the most used web applications are specified as Web 2.0 tools. The concept of Web 2.0 was first introduced at a conference by Tim O'Reilly. O'Reilly (2005) states that the concept of Web 2.0 is the communication network as a platform that includes all devices connected to the network, and also declares that the main advantages of this platform are Web 2.0 tools. Furthermore, he adds that it is possible to create software that is constantly updated since it can be used by many people, and that mixed data from both individual users and multiple sources can be used by collecting, and that this collected data can be used by all users to reveal their own data. It is also emphasized that the most important issue which enables the Web 2.0 platform to go beyond the page metaphor of the Web 1.0 platform is that it creates network effects through the "achitecture of participation" (O'Reilly, 2005). Enonbun (2010) describes Web 2.0 tools as "the radical shift from the monopolistic and static use of the Internet to a more proactive and interactive platform" (p. 20). Unlike the applications used so far, Web 2.0 tools are defined as the social use of the web, where individuals can collaborate, produce information, share information and take an active role in creating content on an online platform (Grosseck, 2009). The main difference between Web 1.0 and Web 2.0 is that the materials published in Web 1.0 tools can only be controlled by the authorities of the web page, and users will not be able to contribute in any way (Walker \& White, 2013) and that Web 2.0 tools are not static but interactive, and users can read, write and share. Websites, which are Web 1.0 tools, are only used for getting information and therefore they do not provide the interaction factor that should be avaliable in language teaching. Thus, today, they are not preferred as Web 2.0 tools. As a result, it can be deduced that the most appropriate applications that enable interaction, reading and writing, content production, bidirectional communication, 
collaboration and autonomy, which are the important elements in foreign language teaching, are Web 2.0 tools.

The main purpose of Web 2.0 tools is to enable users to share various contents and benefit from the social interaction and collaboration opportunities provided by the Internet. Web 2.0 tools are also called as social softwares. They provide transformation from web reader to web literacy. Thanks to these applications, the Internet becomes a platform where content is produced, shared and transferred together with the participants rather than an environment where information is prepared and transmitted, and ready information is consumed (Horzum, 2010). As Horzum (2010) emphasizes "Web 2.0 is an umbrella term and it contains tools to implement many applications. Because the ideas that make up the Web 2.0 tools are too complex and too many to implement with a single tool. The name of these tools is also considered as social tools" (p. 605). Among the Web 2.0 tools, wikis, blogs, video sharing websites, podcasts, social networking sites and instant messaging are the most commonly used ones in foreign language teaching.

\section{Blogs}

The term "blog" has emerged as an abbreviation of "weblog" expression. Blogs are defined as websites which are created by individuals or different groups to present personal inputs consist of texts, sound files, pictures and various links (Horzum, 2010). Blogs are also called as "web diaries" because bloggers can use their websites chronologically, like a diary. Blogs can be prepared on any subject and it is very easy to produce, to write content and to upload various files on these blogs. Moreover, there are many hosting provider websites where blogs can be opened for free. Owing to the ease of use and free of charge, blogs are used frequently by individuals of all ages and disciplines. The most significant feature that distinguishes blogs from other websites is that visitors can share their opinions without being connected to other users. Visitors can enter blogs whenever they want and leave their thoughts and comments on any subject (Richardson, 2006). In addition, people using blogs can interact and share various information and have the opportunity to express themselves in different ways. Many new terms related to the use of blogs have been used recently. For example; the person who writes a blog is called "blogger", and the process of updating a blog and adding a link is called "blogging". When blog users are divided into two categories as readers and writers, there is no difference between reading a web page and reading a blog for readers. However, since creating a website requires HTML knowledge and special software, blogging can be regarded as an authoring system without any need for them (Altun, 2005).

Blogs are very popular Web 2.0 tools in foreign language teaching. Blogs allow learners to express themselves and to be creative, so it is thought that they are very useful especially in teaching writing skills. On the other hand, blogs can be considered as the best examples of authentic materials for foreign language learners. Foreign language learners, who follow and interact with the blogs written in their target language, encounter authentic materials, see various uses of the target language, and so they improve their reading skills. As Pinkman (2005) asserts blogs are not only a platform for learners to read authentic 
reading texts or to practice writing but also websites that help them get motivated to develop their reading and writing skills in the target language. Daşkın (2017) summarizes the benefits of using blogs in foreign language teaching from different sources as follows:

- They provide authentic materials and promote real-life-like communication,

- They boost reading skill and motivate learning,

- They direct learners to the other useful resources via hyperlinks,

- They provide a self-expressive learning space for learners,

- They promote creativity, critical thinking and risk-taking,

- They let learners use the language more sophisticatedly as they address to many readers,

- They provide learners with an interactive and collaborative learning environment,

- They support learner autonomy,

- They can develop learners' linguistic competence as they can be designed multimodal and multilingual,

- They enable learners to communicate and interact with other learners all around the world (p. 65).

These mentioned opportunities are very significant in teaching a foreign language and it is going to be very advantageous to use blogs in teaching in an era when information technologies develop and become widespread.

Blogs can be used in two different ways during the teaching process. Teachers can create their own blogs and share information by communicating with teachers and academics from different parts of the world. On the other hand, learners can prepare their own blogs. They can reflect their knowledge, emotions, skills and thoughts in their blogs. The teaching process is enriched with different types of content thanks to these tools. Furthermore, learners can use blogs to create an electronic portfolio to show their development processes and combine their knowledge. Information about the content of the lessons can be shared owing to the use of blogs by learners and teachers. Additionally, they can be used to make discussions with teachers and other learners, to prepare a project and to collaborate. They can also be used for resource, collaboration, getting news and information purposes (Weller, Pegler \& Mason, 2005).

Although there are not many blogs which are prepared and used frequently for the purpose of teaching Turkish as a foreign language, the following blogs stand out in this field. Apart from these blogs, there are also blogs directed by the websites of some Turkish Teaching Centers, blogs created by the instructors and learners during the learningteaching process, and also blogs created and used for academic studies. 
1. https://www.gurkanbilgisu.com/In this blog prepared by Gürkan Bilgisu, who is a Turkish teacher and who works in the field of teaching Turkish as a foreign language, there are many beneficial materials for both teachers and learners in this field. In addition, there are many articles written by the author in order to share his experiences with his collegues and also a library of Turkish teaching resources which he updates every week.

2. https://yabancilaraturkceogretim.blogspot.com/ This blog redirects to the website of the same name and shares various materials. Furthermore, it allows readers to contribute the content.

\section{Wikis}

Wikis are web applications which are frequently used in all areas of life today. The word "wiki" comes from a word meaning "quick" or "fast" in the Hawaian language. The idea of wiki was originated by Ward Cunningham in 1995. Cunningham named the database he developed "WikiWikiWeb", which can be edited easily by a browser (Henderson, 2009, p. 122). In general terms, wikis are web applications in which users organize and publish information on certain topics through collaborative work. In other words, wikis are websites which are similar to a dictionary, encyclopedia or database, and the visitors can make all the edits they want. On these websites, visitors can define any words and add new comments to previously defined words. All of these are linked by the system, so every page can be opened to many pages (Altun, 2005). Horzum (2010) defines wikis as "the writing areas on the Internet that can be created and edited by many authors" (p. 608). Wikis are used easily without the need for specific information. In such a system, every user registered on wiki can interfere with the information presented on the platform, and web pages, which are the products of this interactive work, are created with all the contributions of the users. "The Free Encyclopedia" called Wikipedia is the reason why wikis are used frequently and widely (Ferret, 2006). Researches on the use of wikis in educational settings (Elgort, Smith \& Toland, 2008; Su \& Beaumont, 2008) indicate that in learning environments where wikis are used as collaborative tools, it has been observed that learners can interact effectively with other users, receive feedback very quickly, encourage each other and learn from each other. Moreover, wikis are usually used for information storage. The personal pages and discussion areas humanize the learning experience and support social interaction among learners. They also provide effective, flexible, user-friendly and cost-effective interfaces for collaboration, knowledge creation, archiving and learner interaction (Horzum, 2010). All these oppportunities explain why wikies are preferred for foreign language teaching.

There are some differences between blogs and wikis. Blogs have one author and they are used for static and linear configurations while wikis have collaborative authoring, dynamic content, nonlinear and multi-page configurations (West \& West, 2009). All in all, it can be said that wikis are more effective for collaborative learning than blogs. However, the access for Wikipedia was blocked between 29 April 2017 and 15 January 2020 in 
Turkey. For this reason, even though Wikipedia is not actively used for teaching Turkish as a foreign language, it is not difficult to guess that it will commonly be used day by day.

\section{Video Sharing Sites}

Video sharing sites are websites that allow users to publish and share the videos they want on any subject. It is possible to publish and share all kinds of video formats on these sites. There are various video sharing sites for many different purposes, the most commonly used of which are YouTube and Google Video (Horzum, 2010). These sites, which are used in every field of life, are also frequently used in the field of education. Teachers can share videos with audiovisual elements and so they contribute to the teaching process by using these sites. The other users can also comment on the videos, which supports the interaction. Today, there are sites only used for educational purposes such as Teacher Tube. However, YouTube is one of the most frequently used sites and it is also used for educational purposes. YouTube is used for many different purposes, and there are many video series about teaching Turkish as a foreign language on it. While some of these videos have been prepared institutionally, some have been prepared individually. The major video series published in this field are as follows:

- Presidency for Turks Abroad and Related Communities - 3 dakikada Türkçe (https://www.youtube.com/channel/UCWfJXGs64xNZVjoSp YimZQ)

- LEARNTURKISHCHANNELNEW - (https://www.youtube.com/channel/UCJZvds9RPO czEp8rgy9fQ]

- Mohd Mele - (https://www.youtube.com/watch?v=JCDE0I2ZYoU)

- XOOMdotWS - (https://www.youtube.com/watch?v=xROhPVgir8E)

- TurkishCuisineTV - (https://www.youtube.com/watch?v=PNysCp0Y6Ec)

- OnlineTurkishLessons - (https://www.youtube.com/watch?v=0CwQt0zXxU0)

- Amir Ordabayev - (https://www.youtube.com/watch?v=-lr7Q8YkPkI)

- Önder Çangal-

(https://www.youtube.com/channel/UCJE4R8Qw43WUCiuNtVeKEA)

\section{Podcasts}

The word "podcast" is derived from a combination of two words in English. It was created by combining "pod" from the word "ipod" and "cast" from the word "broadcast". Podcast is an application that provides streaming of voices over the web. It is called as "Oynaticl yayın abonelikleri" in Turkish. Podcasts are used in two different ways in foreign language teaching. Learners can listen to the podcasts prepared by others or they can produce their own podcasts (Rozgiene, Medvedeva \& Straková, 2008). According to Erben and Sarieva (2008), "portability is another distinct advantage of learning through podcasts" (p. 22) because learners can listen and watch podcasts downloaded to smartphones wherever they want. This feature allows learners to practice speaking skills in the target language 
outside the classroom. Podcasts are very convenient for foreign language learners as they are easily created, corrected, published and listened. Since podcasts can broadcast both audio and video, they provide a content presentation which is preferred by learners who learn more easily with audio materials. In addition, podcasts are more economical in many respects than oral presentations. However, they cannot be used for interaction. Thus, it is stated that they are quite convenient to revise previously used materials outside the classroom (Horzum, 2010). Podcasts usually offer 3-5 minutes of mini recordings. They can be used for pre-course preparation in foreign language teaching, having resources on a topic and compensating for the subjects of missed lessons. Moreover, they are operated with portable multimedia devices, and it helps to move the teaching process out of the classroom (Karaman, Yıldırım \& Kaban, 2008). Because of these features, podcasts are very suitable in foreign language teaching.

Podcasts are also widely used in teaching Turkish as a foreign language. Besides podcasts published by learners and teachers, there are podcasts prepared by some institutions. Some podcasts used in teaching Turkish as a foreign language can be listed as follows:

- Turkish Language Institude's podcast

- Learn Turkish with TurkishClass101

- Learn Turkish podcasts

- Fluent in Turkish

\section{Social Network Sites}

Social network sites are the most used Web 2.0 tools in daily life. The most frequently used among these tools are Facebook, Google +, Twitter, Myspace, Instagram, LinkedIn and Edmodo. With the possibilities of information technologies, individuals now benefit from social network sites in sharing knowledge and experience, interacting, collaborating and communicating. The main purpose of these networks is to provide social interaction between users. Considering that most of the learners use these networks in daily life and enjoy it, it is not difficult to predict that using these networks in the teaching process will motivate the learners to learn. These sites can be used as a means of communication, interaction and collaboration in education as well as in daily life. Thanks to these network sites, learners and teachers can communicate, interact and collaborate not only in the classroom but also outside the classroom, and this will create a more meaningful and permanent learning as a result of social interaction. In social network sites, learners can share their content, pictures, audios and videos, make changes whenever they want, leave comment on published content, participate in a discussion on a topic, and even play games. Teachers, on the other hand, can create groups of learners inside and outside the classroom, communicate with their learners and even assign homework through these sites. In addition, teachers can exchange information with their collegues all around the world for their personal and professional development, follow the latest developments 
related to their profession and see different perspectives. It is known that all of these have positive effects on the foreign language teaching process.

Tagging used in social network sites has been very common among users recently. It has been developed as a method to organize a lot of information on the web, and it is done with keywords (Deans, 2008, p. 123). Users can easily access the content about a topic from many different sources by entering the "\#" icon and then these keywords. This provides a very effective ease of use.

Social network sites are frequently used by learners and teachers in teaching Turkish as a foreign language. Facebook pages prepared by academicians working in this field, Edmodo virtual classes created by the instructors and learners in the teaching process, various twitter accounts are the main social network sites used.

\section{Instant Messaging}

Instant messaging is an application by which two or more people collaborate and communicate simultaneously. Collaboration or communication with these tools can take place not only in written message but also via audio or video message. It is even possible to share files and send additional materials with instant messaging tools. Chat, Internet telephony and video conferencing tools are free Web 2.0 tools in the instant messaging category. Google Talk, Yahoo Messenger, Skype and WhatsApp are the most used instant messaging tools (Horzum, 2010). Teten and Allen (2005) states the main five features of instant messaging as follows:

- indication of presence,

- having multi-tasking feature,

- having written records,

- reduced expense,

- being searchable (as cited in Horzum, 2010).

Considering all these features, it can be concluded that instant messaging can be used effectively in foreign language teaching. First of all, being able to commmunicate with one or more people supports cooperation. Since communication and interaction are in a virtual environment, it is also very useful for people who have difficulties in expressing themselves in face-to-face communication.

\section{TEACHING TURKISH AS A FOREIGN LANGUAGE THROUGH DISTANCE EDUCATION}

Today, rapid developments in satellite, radio, television, computer, the Internet and other information technologies affect the structure and form of education. Due to these technologies, educators are now trying to develop new education programs, learning and teaching models. The trend in learning activities is through educational environments where teachers and learners are in different places, and communication is provided with 
information technologies regarless of which language is spoken. Many educators using information technologies state that the applications called "global education" should be used in the education process. Distance education is one of the most important models offering global education. The first implementation of distance education was via mail in 1728. However, distance education is now carried out in the form of more qualified teleconferencing and Internet applications. Teachers and learners, who are in different places, can communicate effectively both visually and audibly thanks to distance education applications. Additionally, when learners feel psychologically and physiologically ready, they have the opportunity to carry out learning activities with an understanding of education beyond the walls (Hamutoğlu, Horzum \& Okur, 2016; İşman, 2011). In virtual classrooms created by distance education, teaching can now be conducted in many different environments. Interaction, which is one of the most significant parts of the learning process, can be supported by different technologies. First of all, what distance education exactly means should be emphasized. Distance education is defined by Yang (2008) as "a way to enter flexible education opportunities" (p. 586) by using information technologies. Distance learning or distance education is the field of education that deals with the education system, technology and pedagogy where learners and teachers communicate synchronously and / or asynchronously (Al-Arimi, 2014). Yalın (2003) also defines distance education as "a system in which teachers and learners who are physically in separate places interact (perform teaching and learning activities) through technology (TV, video, computer, written materials, etc.)" (p. 202). Based on these definitions, it is deduced that the most prominent feature of distance education is that teachers and learners are not in the same place and the interaction between them is provided with different technologies. As Hamutoğlu et al. (2016) declare:

"Developments in information and communication technologies meet the needs of learners' profiles; and they are moving towards decreasing the distances and increasing the interaction of different languages in the world. This brings the educational environments beyond the walls. The walls of traditional classroom lose one brick everyday. It has been replaced by the concepts such as wireless communication in information and communication technologies, independent learning, self-learning, etc." (p. 18).

It is not difficult to estimate the extent to which distance education contribute to these concepts. The most significant features of distance education are that there is no place and time limitation, education can be received synchronously and asynchronously, they provide continuous education opportunities, they can meet the needs of individuals due to their modular structure, they enable interactive education, they offer assessment and evaluation tools that can be updated easily, and that they can reach large audiences and so they enable the workforce to be used efficiently (Seferoğlu, 2007). Distance education has recently come to the fore as an education model preferred by many institutions because of all these features. 
In foreign language teaching, distance education model is used by different institutions for different purposes. Yalın (2003) describes the purposes of distance education as follows:

- To provide education to large audiences,

- To provide equal opportunities in education,

- To benefit from experts in different places,

- To meet the educational needs of learners who cannot attend courses due to their interests, talents, ages, jobs, and geographical conditions,

- To overcome the limitations of traditional education by providing each individual with the learning environments at the speed and method he/she wishes (p. 202).

Each institution has different needs, and they can evaluate whether to use the distance education model or not in accordance with the above purposes.

There are many benefits of the distance education model in foreign language teaching, where learner autonomy is an important part of learning. The contribution of distance education to the phenomenon of globalization, which is increasingly important today, can be considered as one of its most important benefits. In addition, Halis (2002) lists the advantages of distance education as follows:

- eliminates problems in place and time,

- democratizes the educational process,

- provides lifelong learning,

- self-learning takes place through individual education,

- special skills develop in learning,

- $\quad$ self-confidence improves as a result of self-learning,

- motivates the learners to a certain extent, provides continuity and mobility in learning,

- three-dimensional integration is ensured with press and media, communication tools and face-to-face education,

- education is conducted based on information technologies,

- provides motivation for unlimited and indefinite education by increasing the desire for education,

- provides standardized education opportunities,

- provides flexible and objective assessment and evaluation, 
- $\quad$ provides teacher training. More people benefit from these educators due to the small number of educators specialized in distance education. It sheds light on those who are interested in the subject,

- education costs are reduced. It is lower than traditional methods. There are no expenses such as travel, shelter, etc.

- shows educational consistency independently from the environment, learner, teacher and other environmental conditions,

- increases the interest in education owing to individual participation, mutual interaction and increased success (p. 168-169).

In addition to these, Demirel, Seferoğlu and Yağcı (2003) state that the workforce can be used more efficiently thanks to distance education. Employees can get the education they want without leaving their institutions, so that they can increase their knowledge and skills and find more efficient work opportunities in their institutions. As a result of all the mentioned benefits above, the contribution of distance education to foreign language teaching is an undeniable fact. However, the issue to be considered here is the contribution of the teachers to the process; because in today's distance education environments, information technologies form the communication channels and teacherlearner interaction is very important. For this reason, teachers have very important tasks. The role of the teacher in the information society is not to transfer the target information to the learners but to be a stakeholder in the learning process, to be a kind of mediator between the learners and the information sources, to create learning opportunities, and to organize the learning-teaching process. There are many components in distance education environments such as learners, teachers and materials including multimedia applications. Therefore, it requires serious expertise and responsibility for teachers to take students from different locations and bring them to distance education environments that they create at an equal distance to everyone (Gülbahar, 2012).

There are some studies on teaching Turkish as a foreign language through distance education. Anadolu University Turkish Certificate Program is one of the first studies in this field. The program, which started in 2006 with the participation of many faculties of Anadolu University, is being carried out as a project. The materials from various units are brought together by the Computer Assisted Education Unit and converted into e-learning materials and published on the Internet (Yücer, 2011). However, instead of this project, Anadolu University has contributed to teaching Turkish as a foreign language via distance education under the name of "Ana-dil Türkçe" recently. This program is available at https://turkce.anadolu.edu.tr/. The program, which is used free of charge after a short registration process, provides Turkish education at A1, A2 and B1 levels. There are seven units at the A1 level, five at the A2 level, and eight at the B1 level. In each unit, there are module activities under the title of "eDers", which are in line with the Common European Framework of Reference for Languages. These activities have been prepared within a thematic approach with real life subjects and enriched with animation videos and 
interactive applications. In "Video dersler" section, there are lecture videos specifically explained by the lecturers and they are supported with subtitles in different languages. In "Ses dosyaları ve metinler" section, there are various dialogues which are easily accessed from anywhere and short content to enhance listening, comprehension, reading and comprehension skills of subjects taught in "eDers". In "Oyun" sections, different game applications prepared to reinforce what is taught in the unit aim to increase the motivation by making language learning fun. In addition, users get points from the completed sections within the unit and leveled up, which motivates them to continue studying. Learning outcomes of each unit are available in a separate section and users are informed about the unit objectives. This program stands out as a very useful program for learners of Turkish as a foreign language. If it is prepared with other levels in the Common European Framework of Reference for Languages (B2, C1, C2), it will make a great contribution to the field.

Another program prepared for teaching Turkish as a foreign language is "Uzaktan Türkçe Öğretim Portalı", which is conducted by Yunus Emre Institute and available at https://turkce.yee.org.tr/tr. All levels within the Common European Framework of Reference for Languages are available in this program. The program, which is going to be used free of charge until December 31, 2020, has been also designed for mobile devices. The program, which includes sixty-three different teaching activities to improve different language skills such as reading, listening, writing and speaking, offers the opportunity to learn Turkish by having fun. Each module has preliminary preparation, vocabulary, reading, listening, writing, speaking and evaluation activity groups. In addition to the activity groups, grammar, video and free zone activities are also offered to users in many modules. For learners who are interested in grammar, there are module-based, multilingual grammar sections. In this way, it is aimed to increase the level of student's readiness. Moreover, with "Kelime Öğreniyorum" module, which is only for vocabulary learning, learners can do word learning activities whenever they want. Besides, there are also video lessons in this program. In these lessons, users can receive online tutoring in virtual classrooms. This opportunity can be considered as the most important feature that makes this program different from the others. In addition, users can accumulate points and diamonds with the activities they complete and can shop from the virtual market. The users get experience points from the activities they do in the system, thus, they are encouraged to do more activities. The rank of the users in the system is determined by the experience points they receive. All these trigger the motivation for competition and the motivation to learn significantly increases with game-based activities (Yunus Emre Enstitüsü, 2019).

Another program actively used is "Türkçe Öğreniyorum" project, which is prepared under the auspices of Yaşar University and conducted with the contributions of Yaşar University Open and Distance Learning Center. This program is available at https://turkish.yasar.edu.tr/. This program has been developed within the scope of the project titled "Differentiated Distance Education of Turkish as a Foreign Language" which 
is supported by TÜBİTAK. The target audience of this project is individuals who want to come to Turkey for education and traveling, and individuals who want to cooperate with Turkey. These individuals are offered a basic level of Turkish for free. The project only provides instruction at A1 level within the Common European Framework of Reference for Languages. This program, which is prepared in accordance with the content of Yunus Emre Institute and TÖMERs, includes fifty-three sections, vocabulary and rules dictionary, forum and virtual meeting application. In each section, there are lecture videos, drama videos linking the subject with real life, listening, writing, reading and pronunciation activities as well as games. Moreover, English, Russian, Arabic and French language supports are also provided to users in the system (Yaşar Üniversitesi, 2018).

Another program is "İnternet Üzerinden Türkçe Öğretim Projesi" initiated by Ankara University TÖMER and supported by TÜBİTAK. The website www.distance-turkish.com was launched in 2003 with the aim of spreading the Turkish language and culture and making it available to people all over the world, and Turkish was taught as a foreign language for a fee. However, this program is not currently used.

"Yabancllar için 3 boyutlu Türkçe Öğretimi platformu (HUSIM)" prepared by Hacettepe University Distance Education Application and Research Center is also a program which is currently studied on this field. On this platform, after installing the application on their computers, learners can create their own characters in a three-dimensional environment, perambulate the virtual campus, interact with other characters they encounter through conversation windows and listen to classes when they enter the classrooms. Furthermore, when they go to the education building, they can gain their learning outcomes, and when they go to the assessment and evaluation building, they can test what they learn. Morever, they can improve their vocabulary knowledge by going to the sections such as zoo and greengrocer on the virtual campus. The most important difference that distinguishes this program from the others is that it is three-dimensional and it shapes the learning as learners wish, just like a computer game. It is quite clear that this program will contribute to the learning of Turkish for foreigners and motivate them to learn. However, this program is not finished yet and studies on it are going on.

Apart from all these programs, there are some applications such as iTalki, Verbling, AmazingTalker, Preply and Eurekly and they bring the users who want to learn and teach Turkish as a foreign language together. Such applications cover many languages, including Turkish, and bring the learners and teachers together on their own platform. Through these programs, users from different parts of the world communicate with each other. The tuition fees determined by the teachers who are approved owing to the documents they upload to the system are also received from the learners and transmitted to the teachers through this platform.

As can be seen, although many studies on the distance learning model and different technologies are continuing in the field of teaching Turkish as a foreign language, there are still some deficiencies. Many studies have contributed to this field, but many more applications are needed in teaching Turkish, which is a language spoken by lots of people 
in the world. The reason for the current deficiencies is primarily the focus on teaching Turkish as a mother tongue until now. With revealing the differences between teaching a language as a mother tongue and a foreign language, studies in this field are getting faster. Yücer (2011) states the problems of teaching Turkish through the Internet as follows and emphasized that significant progress is possible only with the studies to be carried out on these issues:

- The government does not have a policy on teaching Turkish through the Internet.

- Comprehensive studies remained at university level and project level in general.

- No distinction was made according to different age groups and educational levels.

- Apart from Anadolu University Turkish Certificate Program and Ankara University Turkish Learning Center, there is no website that teaches Turkish comprehensively, programmatically and systematically.

- The studies are not differentiated as teaching Turkish to Turks or foreigners. However, the applications and activities for two groups should be different from each other.

- The language of instruction on some websites, including Ankara University UTÖM, is English.

- It is not taken into account that language teaching is also teaching culture. While the elements of Turkish culture are expected to be more in the material contents examined, their percentage is found to be low.

- The advertisement of professional websites is not enough.

- There is no certain standard for the placement tests available on almost every website.

- On many websites, learning content has remained at some point, it has not improved and updated.

- The products used on the websites remained at the material level for using in Turkish lessons (p. 139-140).

New studies on some of the mentioned problems are being done and these problems are eliminated gradually. For example; it is noticed that the coursebooks of teaching Turkish as a foreign language, which have been prepared recently, are designed according to different age groups. Moreover, recently, it has gained awareness that teaching a mother tongue and a foreign language are significantly different from each other, and studies have progressed in this direction. In addition, being aware of the importance of culture transfer in foreign language teaching, cultural elements have been included in the studies and materials prepared, which has led to important developments in the context of cultural transfer. Besides all these positive improvements, there are still problems that cannot be solved. To illustrate, some of the projects prepared for teaching Turkish as a foreign 
language through distance education have been terminated and some of the prepared website contents have remained at the material level without showing any improvements. It takes time to troubleshoot and progress in this increasingly important field, but the recent studies show a positive trend.

Consequently, in order to use information technologies more effectively in teaching Turkish as a foreign language, firstly, it is necessary to determine the teaching objectives and the needs of learners. The teachers can then decide which application to use and how much they should use these applications. Furthermore, to use these technologies more functional in the teaching process, it would be appropriate to talk about the suggestions that Odabaş (2012) made regarding which application to use according to different goals. These suggestions are as follows:

- If learners are required to be more active; social networks (Facebook, myspace, Twitter),

- If teachers want to emphasize group work and collaboration; wikis (wikipedia, wikihost, @wiki),

- If the instructor should be in the foreground and the learners are required to act with directions; blogs (Blogcu, blogger, benimblog, wordpress),

- If the listening / watching activities are planned prominently; podcasts or open video sharing sites (Youtube, vidivodo, izlesene; mbirgin podcast),

- If learners are required to practice in real world conditions, it may be appropriate to prefer virtual world programs (Google earth, Microsoft virtual earth). (as cited in Göçmenler, 2015, p. 243-244).

\section{CONCLUSIONS AND SUGGESTIONS}

Considering all information technology applications used in foreign language teaching, it can be said that these applications create opportunities to perform constructivist learning activities. Teaching through these practices turns into a process where individual differences are at the forefront, and learners and teachers interact and collaborate. It also allows learners and teachers to share information globally by taking the learning process out of the classroom.

In addition to these, especially Web 2.0 tools are the applications that support collective intelligence with collaboration and innovations. Collective intelligence tends to be used as a new model of learning and teaching. This intelligence is a skill developed by individuals through new mechanisms such as differentiation, integration, competition and cooperation. (CI, 2009; Horzum, 2010). Individuals who go through the learning process using these applications learn more effectively because they can receive education in their own intelligence types and contribute to lifelong learning processes with the different skills they acquire. 
Besides the advantages of using information technologies in foreign language teaching, there are of course some disadvantages. These can be listed as a) security and privacy, b) inappropriate content, c) lack of communication, d) time consuming, e) cyberbullying and f) unreal friendship (Griffith \& Liyanage, 2008; Zaidieh, 2012). However, it is possible to prevent these disadvantages under the guidance of the teacher during the teaching process. The teachers can only guide the process correctly with their knowledge about these practices and the education they receive.

The number and variety of applications which use information technologies in teaching Turkish as a foreign language are increasing day by day. However, it should not be forgotten that the applications prepared with the developing technologies can always be developed. It is seen that especially abroad where Turkish is taught as a foreign language, there is more need for such applications. Individuals who only encounter Turkish, their target language, in the educational environment can use Turkish only with the help of information technologies outside these environments. Therefore, it is possible to say that developing applications that contribute to teaching Turkish as a foreign language especially abroad, making use of these applications more frequently and encouraging learners to use these applications will contribute a lot to this field.

\section{References}

Al-Arimi, A. M. A. (2014). Distance learning. Social and Behaviour Sciences, 152, 82-88.

Altun, A. (2005). Eğitimde internet uygulamaları [Internet applications in education]. Ankara: Anı Yayıncilık.

Büyükaslan, A. (2007, Mayıs). Yabancı dil Türkçenin öğretilmesinde yeni yöntemler: Bilişim uygulamaları, çözüm önerileri [New methods in Turkish as a foreign language: Information applications, solution offers], Conference paper presented at the $1^{\text {st }}$ Symposium on Computer and Instructional Technologies. Çanakkale.

Chen, J., Belkada, S., \& Okamoto, T. (2004). How a web-based course facilitates acquisition of English for academic purposes. Language Learning \& Technology, 8(2), 33-49.

CI (2009, 12 July). Collective intelligence. Retrieved from http://www.community-intelligence.com

Daşkın, Z. (2017). A study of faculty members' and instructors' awareness, routines and use of web 2.0 tools in foreign language teaching (Master's thesis). Hacettepe University, Ankara.

Deans, P. C. (2008). Social software and web 2.0 technology trends. New York: Information Science Reference.

Demirel, Ö., Seferoğlu, S. S., \& Yağcl, E. (2003). Öğretim teknolojileri ve materyal geliştirme [Instructional technologies and material development]. Ankara: Pegem Yayıncllı.

Driscoll, M. (1998). Web - based training. San Francisco: Jossey-Bass Pfeiffer.

Durmuş, M. (2019). Dil öğretiminde öğretici yeterlilikleri ve pedagojik muhakeme becerisi [Teaching competencies and pedagogical reasoning skills in language teaching]. Ankara: Grafiker Yayınları.

Duru, H. (2013). Yabancı dil Türkçe öğretiminde yazıll, işitsel, görsel araçlar ve dil öğretim ortamları [Written, audio, visual aids and language teaching environments in teaching Turkish as a foreign 
language]. In M. Durmuş. \& A. Okur. (Eds.), Yabancılara Türkçe öğretimi el kitabı [The handbook of teaching Turkish to foreigners] (pp. 395-412). Ankara: Grafiker Yayınları.

Elgort, I., Smith, A., \& Toland, J. (2008). Is viki an effective platform for group course work. Australasian Journal of Educational Technology, 24(2), 195-210.

Enonbun, 0. (2010). Constructivism and web 2.0 in the emerging learning era: A global perspective. Journal of Strategic Innovation and Sustainability, 6(4), 16-25.

Erben, T., \& Sarieva, I. (2008). CALLing all foreign language teachers: Computer-assissted language learning in the classroom. Larchmont, NY: Eye on Education, Inc.

Ferret, L. J. (2006). Vikis and e-learning. In P. Berman (Ed.), E-learning concepts and techniques (pp. 7374). Bloomsburg, PA: Bloomsburg University.

Göçmenler, H. (2015). Yabancılara Türkçe öğretiminde materyal geliştirme ve teknoloji kullanımı [Material development and technology use in teaching Turkish to foreigners]. In A. Sarıçoban (Ed.), Yabancı dil olarak Türkçe öğretimi metodolojisi [Teaching methodology for Turkish as a foreign language] (pp. 213-255). Ankara: Anı Yayıncılık.

Griffith, S., \& Liyanage, L. (2008). An introduction to the potential of social networking sites in education. In I. Olney, G. Lefoe, J. Mantei \& J. Herrington (Eds.), Proceedings of the Second Emerging Technologies Conference (pp. 76-81). Wollongong: University of Wollongong.

Grosseck, G. (2009). To use or not to use web 2.0 in higher education? Social and Behavioral Sciences, 1 , 478-482.

Gülbahar, Y. (2012). E-öğrenme [E-learning] (2nd ed.). Ankara: Pegem Akademi.

Gün, S. (2015). Yabancl dil olarak Türkçenin öğretiminde web 2.0 sesli ve görüntülü görüşme uygulamalarının (skype) konuşma becerisine etkisi [The effect of web 2.0 voice and video call applications (skype) on speaking skills in teaching Turkish as a foreign language] (Master's thesis). Çanakkale Onsekiz Mart University, Çanakkale.

Halis, İ. (2002). Öğretim teknolojileri ve materyal geliştirme [Instructional technologies and material development]. İstanbul: Nobel Yayıncllık.

Hamutoğlu, B., Horzum, M. B., \& Okur, A. (2016). Yurt dışındaki Türkçe öğretmenlerinin uzaktan eğitime yönelik hazır bulunuşluklarının (UEYHB) değişimi [Changes in the readiness of Turkish teachers abroad for distance education]. In A. Okur, B. İnce \& İ. Güleç (Eds.), Yabancılara Türkçe öğretimi üzerine araştırmalar [Studies on teaching Turkish to foreigners] (pp. 17-26). Sakarya: Sakarya University TÖMER.

Henderson, H. (2009). Encyclopedia of computer science and technology. New York, NY: Facts on File.

Horzum, M. B. (2010). Öğretmenlerin web 2.0 araçlarından haberdarlığı, kullanım sıklıkları ve amaçlarının çeşitli değişkenler açısından incelenmesi [Investigating teachers' web 2.0 tools awareness, frequency and purposes of usage in terms of different variables]. Journal of Human Sciences, 7(1), 603-634.

İşman, A. (2011). Uzaktan eğitim [Distance education]. Ankara: Pegem Akademi.

Karaman, S., Yıldırım, S., \& Kaban, A. (2008). Öğrenme 2.0 yaygınlaşıyor: Web 2.0 uygulamalarının eğitimde kullanımına ilişkin araştırmalar ve sonuçları [Learning 2.0 is spreading: Research and results on the use of web 2.0 applications in education]. In M. Akgül, E. Derman, U. Çağlayan \& A. Özgit (Eds.), Inet-tr'08 - XIII. Türkiye'de Internet Konferansı Bildirileri [Proceedings of Inet-tr'08Internet in Turkey Conference] (pp. 35-40). Ankara: Middle East Technical University.

Karasar, N. (2016). Bilimsel Araştırma Yöntemi [Scientific Research Method]. Ankara: Nobel Akademik Yayıncilık. 
O'Reilly, T. (2005, 15 Ocak). Web 2.0: Compact definition? Retrieved from http://radar.oreilly.com/2005/10/web-20-compact-definition.html

Pinkman, K. (2005). Using blogs in the foreign language classroom: Encouraging learner independence. The Jalt CALL Journal, 1(1), 12-24.

Richardson, W. (2006). Blogs, vikis, podcasts, and other powerful web tools for classrooms. Thousand Oaks, CA: Corwin Press.

Rozgiene, I., Medvedeva, O., \& Strakova, Z. (2008). Integrating ICT into language learning and teaching: Guide for tutors. Wien: Johannes Kepler Universitat Linz.

Seferoğlu, S. (2007). Öğretim teknolojileri ve materyal tasarımı [Instructional technologies and material design]. Ankara: Pegem Akademi.

Su, F., \& Beaumont, C. (2008, Haziran). Student perceptions of e-learning with a Viki. Conference paper presented at SOLSTICE Conference 2008: E-learning and Learning Environments for the Future. Edge Hill University, Ormskirk.

Şengül, M. (2012). Yabancı dil olarak Türkçe öğretiminde öğretim teknolojileri ve materyal kullanımı [Instructional technologies and use of materials in teaching Turkish as a foreign language]. In A. Kılınç \& A. Şahin (Eds.), Yabancı dil olarak Türkçe öğretimi [Teaching Turkish as a foreign language] (pp. 167-188). Ankara: Pegem Yayıncllı.

Teten, D., \& Allen, S. (2005). The virtual handshake: Opening doors and closing deals online. New York, NY: AMACOM.

Uzunboylu, H. (2005). The effectiveness of web assisted English language instruction on the achievement and attitude of the students. In L. Cantoni \& C. McLoughlin (Eds.), Proceedings of EDMEDIA 2004 World Conference on Educational Multimedia, Hypermedia \& Telecommunications (pp. 727-733). Lugano, Switzerland: Association fort he Advancement of Computing in Education (AACE).

Ünsal, H. (2012). Harmanlanmış öğrenmenin başarı ve motivasyona etkisi [The effect of blended learning on success and motivation]. Journal of Turkish Educational Sciences, 10(1), 1-27.

Walker, A., \& White, G. (2013). Technology enhanced language learning: Connecting theory and practice. Oxford: Oxford University Press.

Wang, S. \& Vasquez, C. (2012). Web 2.0 and second language learning: What does the research tell us? CALICO Journal, 29(3), 412-430.

Weller, M., Pegler, C., \& Mason, R. (2005). Use of innovative technologies on an e-learning course. Internet and Higher Education, 8, 61-71.

West, J. A. \& West, M. L. (2009). Using wikis for online collaboration: The power of the read-write web. San Francisco: Jossey-Bass.

Yalın, H. İ. (2003). Öğretim teknolojileri ve materyal geliștirme [Instructional technologies and material development]. Ankara: Nobel Akademik Yayıncllık.

Yang, M. (2008). Rethinking lifelong learning through online distance learning in Chinese educational policies, practices and research. British Journal of Educational Technology, 39(4), 583-597.

Yaşar Üniversitesi. (2018, 19 March). Türkçe öğreniyorum [I'm learning Turkish]. Retrieved from https://turkish.yasar.edu.tr/

Yunus Emre Enstitüsü. (2019, 15 January). Türkçe eğitim portal [Turkish education portal]. Retrieved from https://turkce.yee.org.tr/tr

Yücer, S. (2011). İnternet yoluyla Türkçe öğretimi ve sorunları [Teaching Turkish via the Internet and its problems]. Gazi University Academic Student Journal of Turkish Studies, 1, 132-143.

Zaidieh, A. J. Y. (2012). The use of social networking in education: Challenges and opportunities. World of Computer Sciences and Information Technology Journal, 2(1), 18-21. 